\title{
Faculty Members' Instructional Priorities for Adopting OER
}

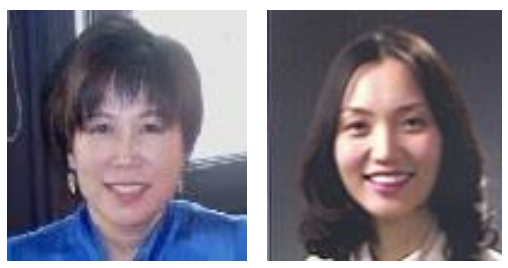

Insung Jung ${ }^{1}$ and Seongyoun Hong ${ }^{2}$

1/nternational Christian University, Japan, ${ }^{2}$ Ajou University, Korea

\begin{abstract}
This study aimed to investigate and classify faculty members' instructional priorities for adopting OER. In-depth interview data were collected from 10 faculty members from different regions and analyzed with NVivo 10. The original supposition was that the well-established instructional priorities, effectiveness, efficiency, and appeal would apply. However, it was found that in adopting OER, these faculty members had four instructional priorities: effectiveness, efficiency, appeal, and extension. Effectiveness was the most important consideration, followed by extension, appeal, and efficiency. Regional differences were also apparent. These findings were drawn upon to propose an elaborated model of instructional priorities for adopting OER.
\end{abstract}

Keywords: appeal, effectiveness, efficiency, extension, instructional priorities, OER use

\section{Introduction}

Since the year 2000, freely available open educational resources (OER), defined as "teaching, learning, and research resources with an intellectual property license that permits them to be reused, reworked, remixed, and redistributed" (D'Antoni, 2009, p.3), have gained the attention of faculty. Various types of OER exist; OER can be: full courses, course materials, modules, learning objects, textbooks, steamed videos, software, tests, assignments, case studies, e-portfolio, training materials, practice items, etc. OER can be divided by content type into several categories: text-based, audiobased, video-based, game-based, and multiple media. They may be static content, dynamic resources, a set of activities, or cases. Different types of OER can meet different needs and impact teaching and learning differently (Hylén, 2006). However, it is generally posited that OER have the potential to meet the increasing demand for higher education and enable educational institutions to serve geographically, socially, economically, or otherwise excluded learners, serve the needs of informal, non-formal and formal education, help provide articulation arrangements between various sectors of 
education and improve the quality of education by offering multimedia resources and choices at little or no additional cost (Butcher, 2011; Dhanarajan \& Abeywardena, 2013; McGreal, 2013; Wiley, 2008).

However, as shown by Conole (2012) and Murphy (2013), while many OER repositories have been established by institutions, faculty are not widely or effectively using these resources. Jung, Sasaki, and Latchem (2016) identify a number of inter-related reasons for this. Firstly, there is a multitude of sources and distribution channels. Reynolds (2012) asserts that it is difficult to locate OER and ascertain their benefits. Leacock and Nesbit (2007) argue that sifting through numerous repositories is time-consuming and impractical. Groom (2013) reports on the problems of lack of consistent metadata, repositories using differing protocols for communicating with other software, lack of clear licensing information, the difficulty of distinguishing OER from other digital content, and broken links. Falconer, McGill, Littlejohn, and Boursinou (2013) state potential users' concerns about the relevance and quality of OER are important obstacles to OER use while Dhanarajan and Abeywardena (2013) find that faculty's lack of knowledge and skills in evaluating the quality of OER are also inhibiting their adoption and use.

D'Antoni (2009), McGreal, Kinuthia, and Marshall (2013), and Conole (2012) report that research into OER tends to concern their development rather than their utilization. Kortemeyer (2013) posits that OER have not affected traditional teaching and learning models in most higher education institutions. Petrides, Jimes, Middleton-Detzner, Walling, and Weiss (2011) discovered that while reduced cost, dependable quality, and ease of use were the main reasons for open textbook adoption, these resources were used in ways reflecting existing practices. Wiley, Bliss, and McEwen (2014) discovered that instructors tend to use and reuse the OER as they are, rather than making an effort to revise, remix, and repurpose. In Tanzania, Mtebe and Raisamo (2014) found that faculty adopted OER for reasons of effort expectancy (ease of locating, assessing, and adapting or using OER) rather than pedagogical considerations. Other studies including Buabeng-Andoh (2012) revealed that factors such as well-established infrastructure, continuous and on-demand training opportunities, technical support, leadership support and other organizational support positively affected teachers` ICT adoption. These findings imply that when OER are developed and introduced at the institutional level, individual faculty members are more likely to adopt OER for reasons of supportive facilitating conditions and low effort expectancy.

OER adoption studies employing the Technology Acceptance Model (TAM), an information systems theory that models how users come to accept and use a technology in terms of perceived usefulness (or performance expectancy) and ease-of-use (or effort expectancy), tend to focus on the practical or functional aspects of technology adoption rather than the all-important pedagogical considerations.

In recent years, there has been increased interest in the pedagogical aspects of OER among higher education researchers and practitioners. For example, in the context of Canadian higher education, Jhangiani, Pitt, Hendricks, Key, and Lalonde (2016) surveyed the various reasons for using OER in classroom teaching and established that the three principal reasons were: 1) developing ideas and inspiration, 2) supplementing existing coursework, and 3) preparing for teaching. The JISC/Higher Education Academy's UK OER Programme (Joint Information Systems Committee, n.d.) and the Open University's SCORE (SCORE, n.d.) have attempted to gain a fuller understanding of the ways in 
which OER are used in UK universities. They show that faculty's use of OER depends upon their academic preference and judgment. However, none of the above studies offer a conceptual framework for assessing the pedagogical reasons for OER adoption. The current study therefore aimed to investigate and classify faculty's instructional priorities for OER adoption from the pedagogical perspective by applying three well-established instructional priorities: effectiveness, efficiency, and appeal (Reigeluth \& Carr-Chellman, 2009) as a framework for initial data analysis. It sought to answer the following questions:

1. Is the general framework based on these three instructional priorities applicable in explaining pedagogical considerations for OER adoption in higher education?

2. Could an elaborated model be proposed to define and explain pedagogical considerations in adopting OER?

3. Are there any differences in instructional priorities of OER adoption across cultures and how can such differences be reflected in future OER research and development?

\section{Theoretical Underpinning}

The main reason for initially basing this study upon the three instructional priorities of effectiveness, efficiency, and appeal, is that they are widely used to categorize instructional purposes or outcomes (Reigeluth, 1999; Wilson, Parrish, \& Veletsianos, 2008). Honebein and Honebein (2015) find that instructional designers' and adopters' decisions are not typically based upon theory but that just as trade-offs are needed between time, scope, and cost (Cuellar, 2010), instructional designers and course providers have to consider whether their priorities lie in the effectiveness, efficiency or appeal of the methods/resources. As defined by Honebein and Honebein (2015), Jung et al. (2016), and Reigeluth and Frick (1999), effectiveness concerns the extent to which the application of an instructional method helps achieve a learning outcome; efficiency is a measure of the time and/or cost involved in instruction; and appeal is a measure of continuing student enjoyment and participation in the learning. So for example, in considering the merits of particular OER, adopters may conclude that the focus on cognitive content will dilute the appeal of a resource, or the focus on affective and psychomotor content may reduce the efficiency of an OER, or a focus on textual content with no interaction or capacity to easily be changed or adapted may lessen the effectiveness of an OER. Honebein and Honebein (2015) posit that while effectiveness and efficiency are directly related to the success of instruction, in the digital age, appeal (attention, motivation, and flow in learning) might often be the most important priority. Doering and Veletsianos (2008) argue that in today's open digital world educators should also consider such factors as engagement, social justice, and transformation.

So while the current study adopted the three instructional priorities as a tool for initially analyzing the data, the researchers were also open to the possibilities of other pedagogical considerations applying in the adoption of OER for teaching and learning. 


\section{Methodology}

\section{Cases}

Cases were solicited across various regions via three resource persons: an editor-in-chief of an international journal on open education, a South Africa-based OER strategist, and an OER developer and researcher in an Asian distance teaching university. The cases were to concern faculty making regular use of OER in their teaching and learning. They were also to be from different regions and cultures. Of the ten cases finally selected, four were from Asia, two from North America, two from Africa and two from Europe. The faculty surveyed varied in their teaching experiences and level of OER adoption. Some simply used YouTube videos while others revised and repurposed existing OER to meet their own teaching needs. In all cases individual faculty members made a final decision to use OER for their own teaching. However, in cases 1, 3, 7, 8, and 9, OER adoption was largely supported and facilitated at the institutional level while in cases $2,4,5,6$, and10, it was solely based on an individual instructor`s decision and effort. Table 1 presents an overview of the 10 cases adopted.

Table 1

Overview of the 10 Cases Included in the Study

\begin{tabular}{|c|c|c|c|c|c|}
\hline $\begin{array}{l}\text { Case } \\
\#\end{array}$ & $\begin{array}{l}\text { Region/ } \\
\text { Country }\end{array}$ & $\begin{array}{l}\text { Teaching } \\
\text { Experience }\end{array}$ & $\begin{array}{l}\text { Course Title } \\
\text { (Level) }\end{array}$ & $\begin{array}{l}\text { Teaching } \\
\text { Context }\end{array}$ & $\begin{array}{l}\text { OER Types Used in } \\
\text { Teaching }\end{array}$ \\
\hline $\begin{array}{l}\text { Case } \\
1\end{array}$ & $\begin{array}{l}\text { Asia/ } \\
\text { China }\end{array}$ & $3 \mathrm{yrs}$ & $\begin{array}{l}\text { Educational } \\
\text { research } \\
\text { methods } \\
\text { (Master's) }\end{array}$ & $\begin{array}{l}\text { Blended } \\
\text { (F2F with online } \\
\text { components) }\end{array}$ & $\begin{array}{l}\text { Learning Cell (various } \\
\text { types of OER developed } \\
\text { at institutional level and } \\
\text { created by students) - } \\
\text { http://lcell.bnu.edu.cn/lo } \\
\text { gin.jsp?lan=en }\end{array}$ \\
\hline $\begin{array}{l}\text { Case } \\
2\end{array}$ & $\begin{array}{l}\text { Asia/ } \\
\text { Japan }\end{array}$ & 13 yrs & $\begin{array}{l}\text { Media } \\
\text { communication } \\
\text { (Advanced } \\
\text { undergraduate) }\end{array}$ & $\begin{array}{l}\text { Blended } \\
\text { (F2F with online } \\
\text { components) }\end{array}$ & YouTube videos \\
\hline $\begin{array}{l}\text { Case } \\
3\end{array}$ & $\begin{array}{l}\text { Asia/ } \\
\text { Malaysia }\end{array}$ & $5 \mathrm{yrs}$ & $\begin{array}{l}\text { Web database } \\
\text { application } \\
\text { (Intermediate } \\
\text { undergraduate) }\end{array}$ & $\begin{array}{l}\text { Distance } \\
\text { education } \\
\text { (Online and print- } \\
\text { based) }\end{array}$ & $\begin{array}{l}\text { Wikibooks (Revised and } \\
\text { repurposed OER) }\end{array}$ \\
\hline $\begin{array}{l}\text { Case } \\
4\end{array}$ & $\begin{array}{l}\text { Asia/ } \\
\text { Philippin } \\
\text { es }\end{array}$ & $10 \mathrm{yrs}$ & $\begin{array}{l}\text { Instructional } \\
\text { media resources } \\
\text { (Intro } \\
\text { undergraduate) }\end{array}$ & $\begin{array}{l}\text { Blended } \\
\text { (F2F with online } \\
\text { components) }\end{array}$ & $\begin{array}{l}\text { Wikipedia; SlideShare; } \\
\text { YouTube videos; } \\
\text { Knowledge Channel } \\
\text { Online }\end{array}$ \\
\hline $\begin{array}{l}\text { Case } \\
5\end{array}$ & $\begin{array}{l}\text { America/ } \\
\text { Canada }\end{array}$ & Over 20 yrs & $\begin{array}{l}\text { Open education } \\
\text { (Master's) }\end{array}$ & $\begin{array}{l}\text { Distance } \\
\text { education } \\
\text { (Totally online) }\end{array}$ & Various types of OER \\
\hline $\begin{array}{l}\text { Case } \\
6\end{array}$ & $\begin{array}{l}\text { America/ } \\
\text { USA }\end{array}$ & $4 \mathrm{yrs}$ & $\begin{array}{l}\text { Using } \\
\text { computers in } \\
\text { education (Intro } \\
\text { undergraduate) }\end{array}$ & $\begin{array}{l}\text { Blended } \\
\text { (F2F with online } \\
\text { components) }\end{array}$ & Various types of OER \\
\hline $\begin{array}{l}\text { Case } \\
7\end{array}$ & $\begin{array}{l}\text { African/ } \\
\text { Zambia }\end{array}$ & $14 \mathrm{yrs}$ & $\begin{array}{l}\text { Mathematics } \\
\text { pedagogy } \\
\text { (Primary } \\
\text { teachers' } \\
\text { diploma) }\end{array}$ & $\begin{array}{l}\text { Blended } \\
\text { (online and print- } \\
\text { based distance } \\
\text { learning modules } \\
\text { with a few F2F } \\
\text { sessions) }\end{array}$ & $\begin{array}{l}\text { Revised and repurposed } \\
\text { South African Institute } \\
\text { for Distance Education } \\
\text { (SAIDE) OER }\end{array}$ \\
\hline $\begin{array}{l}\text { Case } \\
8\end{array}$ & $\begin{array}{l}\text { Africa/ } \\
\text { S. Africa }\end{array}$ & $15 \mathrm{yrs}$ & $\begin{array}{l}\text { Supporting } \\
\text { teaching } \\
\text { practice through }\end{array}$ & $\begin{array}{l}\text { Blended } \\
\text { (F2F with print- } \\
\text { based distance }\end{array}$ & $\begin{array}{l}\text { Revised and repurposed } \\
\text { SAIDE OER }\end{array}$ \\
\hline
\end{tabular}




\begin{tabular}{|c|c|c|c|c|c|}
\hline & & & $\begin{array}{l}\text { mentoring (In- } \\
\text { service teacher } \\
\text { training) }\end{array}$ & learning modules) & \\
\hline $\begin{array}{l}\text { Case } \\
9\end{array}$ & $\begin{array}{l}\text { Europe/ } \\
\text { Germany }\end{array}$ & $12 \mathrm{yrs}$ & $\begin{array}{l}\text { IT service } \\
\text { management } \\
\text { (Advanced } \\
\text { undergraduate) }\end{array}$ & $\begin{array}{l}\text { Blended } \\
\text { (F2F with online } \\
\text { components) }\end{array}$ & $\begin{array}{l}\text { Revised and repurposed } \\
\text { collections of slides, audio } \\
\text { books, case studies and } \\
\text { practice }\end{array}$ \\
\hline $\begin{array}{l}\text { Case } \\
10\end{array}$ & $\begin{array}{l}\text { Europe/ } \\
\text { Israel }\end{array}$ & Over 20 yrs & $\begin{array}{l}\text { ICT and } \\
\text { learning } \\
\text { (Master's) }\end{array}$ & $\begin{array}{l}\text { Blended } \\
\text { (F2F with online } \\
\text { components) }\end{array}$ & YouTube videos \\
\hline
\end{tabular}

\section{Data Collection}

Following a general ethics code for research, the study proposal was reviewed and approved by the Research Ethics Committee at the first author's university. To identify the various pedagogical reasons for and strategies in adopting OER at three stages of teaching with OER - selection, implementation, and evaluation, the instructors were asked to complete a pre-developed template between June 1 November 30, 2014. In this, they were invited to enter details of the course(s) in which the OER were used, including course objectives and learner characteristics, their experience with teaching and OER use, and the types of OER used. They were asked to explain the criteria or instructional priorities they used in selecting, implementing, and evaluating these OER, and describe in detail why certain OER were selected, how these were used, and what the intended outcomes were in order to identify the instructors' pedagogical reasons for adopting OER at each of the three stages. They were also asked to make comments regarding the effective use of OER.

After submitting the completed template, each instructor participated in one or two Skype or email interviews with the first author between December 1, 2014 and January 15, 2015 in order to expand on their answers and experiences.

\section{Data Analysis}

The analysis comprised five phases: pre-processing, initial coding, elaboration, meaning-making, and modeling. In each phase, two of the authors discussed the analysis results several times until accord was reached.

1. In the pre-processing phase, the template and interview responses were exported to NVivo 10 in order to clean and organize the qualitative data. Responses unrelated to the study or without meaning were eliminated. In total 174 responses related to the pedagogical aspects of OER adoption were used for the initial coding.

2. In the initial coding phase, using each response as an analysis unit, 174 chunks were categorized following the general framework of three instructional priorities. Five codes were created under the effectiveness category, six codes under efficiency, and three codes under appeal.

3. In the elaboration phase, the authors carefully read and re-read all of the responses under each code and category, and clarified the meanings of these responses in order to elaborate the initial coding results. After several rounds of discussions, 40 codes were created (18 under 
effectiveness, 13 under efficiency, and 9 under appeal) with 272 chunks (units of information explaining a single concept) all of which were elaborated from 174 responses.

4. In the meaning-making phase, the coded data were once again classified, clustered, and refined to make sense of data and more clearly depict the pedagogical considerations for OER use in teaching. The 272 chunks were expanded to 279 chunks and categorized into 49 codes under three instructional priorities (20 under effectiveness, 19 under efficiency, and 10 under appeal).

5. It was at this stage that the authors observed that some of the codes and chunks did not accord with the three instructional purposes. After discussion, it was agreed to add a fourth instructional priority, extension, encompassing the codes, and chunks that did not belong to the three priorities. This category was created because it was clear from these codes and chunks indicated that the respondents often used OER to extend learning opportunities, for example through instruction or study outside the traditional classroom methodology, by offering learning options, or aiming for various course level competencies. The authors regrouped all the chunks into 49 codes, and categorized these codes into 14 domains across the four instructional priorities. Domain and code names were then created to highlight the meaning of significant chunks belonged in each category.

6. In the modeling phase, all 14 domains, 49 codes, and 279 chunks were again reviewed and the domain and code names were refined in an attempt to develop an elaborated model which could clarify the pedagogical considerations in adopting OER. After refining and rearranging the codes and chucks accordingly, 35 codes with 285 meaningful chunks were included in the final modeling process and categorized into 14 domains across four instructional priorities (effectiveness, efficiency, appeal, and extension). In the effectiveness category, 133 chunks were placed across 16 codes; in the efficiency category, 35 chunks were located across 6 codes; in the appeal category, 46 chunks were located across 7 codes; and in the extension category, there were 71 chunks across 6 codes.

Responses by region were compared across the four instructional priority categories and subcategories to answer research question 3.

\section{Findings and Discussion}

\section{Considerations for OER Use}

The three instructional priorities - effectiveness, efficiency, and appeal - were found to be applicable in explaining pedagogical considerations for OER use in higher education ( $75 \%$ of the chunks belong to these three categories). The need to add one important pedagogical reason for OER use, extension ( $25 \%$ of the total chunks) was also confirmed. As Table 2 shows, 285 meaningful chunks identified from 174 responses were categorized into four instructional priorities (effectiveness, efficiency, appeal, and extension). 
- In the effectiveness category, four main reasons (Domains in Table 2) for OER use were identified (to offer learner-centered materials, to provide quality content, to employ active learning methods, and to encourage deeper learning).

- In the efficiency category, three main reasons for OER use were identified (time-saving for instructors, time-saving for learners, and resource-saving).

- In the appeal category, four key reasons for OER use were identified (to add variety in learning, to promote flow in learning, to improve motivation, and to offer rich learning experiences).

- In the extension category, three main reasons for OER use were revealed (to offer expanded learning opportunities, to improve sharing and networking, and to provide extended access).

Table 2

Coding and Categorization of Instructional Priorities of Using OER Indicated

\begin{tabular}{|c|c|c|c|}
\hline Instructional & Domains (14) & Cod & les (35) \\
\hline Effectiveness & Learner-Centered & 1) & Add structure for learners ( 4 chunks) \\
\hline 133 chunks & $\begin{array}{l}\text { Materials } \\
\text { (40 chunks) }\end{array}$ & 2) & $\begin{array}{l}\text { Offer materials appropriate to characteristics of learners } \\
\text { (19 chunks) }\end{array}$ \\
\hline$(47 \%)$ in 16 & & 3) & Offer needs-based materials (17 chunks) \\
\hline domains & Quality Content (38 & 4) & Add clarity to learning content ( 7 chunks) \\
\hline & chunks) & 5) & $\begin{array}{l}\text { Help learners understand learning goals and content ( } 4 \\
\text { chunks) }\end{array}$ \\
\hline & & 6) & Offer up-to-dated content (8 chunks) \\
\hline & & 7) & $\begin{array}{l}\text { Supplement examples and significant concepts (16 } \\
\text { chunks) }\end{array}$ \\
\hline & & 8) & Present content in an easy-to-follow manner ( 3 chunks) \\
\hline & Active Methods & & Draw attention to key points ( 2 chunks) \\
\hline & (25 chunks) & 10) & Help independent learning ( 4 chunks) \\
\hline & & 11) & Promote learner-learner interaction (7 chunks) \\
\hline & & 12) & Promote teacher-learner interaction ( 4 chunks) \\
\hline & & 13) & Improve teaching strategies for active learning ( 8 chunks) \\
\hline & Deeper Learning & 14) & Help learners link in- and out-of-class learning ( 6 chunks) \\
\hline & (29 chunks) & 15) & $\begin{array}{l}\text { Help learners relate and apply existing knowledge (10 } \\
\text { chunks) }\end{array}$ \\
\hline & & 16) & $\begin{array}{l}\text { Help learners construct meaningful knowledge (13 } \\
\text { chunks) }\end{array}$ \\
\hline Efficiency & Time-Saving of & 1) & Require less time to adapt and edit ( 8 chunks) \\
\hline 35 chunks & $\begin{array}{l}\text { Instructors } \\
\text { (10 chunks) }\end{array}$ & 2) & Use without revision ( 2 chunks) \\
\hline codes across 3 & Time-Saving of & 3) & Require no training time for use ( 1 chunks) \\
\hline domains & $\begin{array}{l}\text { Learners } \\
\text { (13 chunks) }\end{array}$ & 4) & Save learning time with supportive materials (12 chunks) \\
\hline & Resource-Saving & 5) & Require minimum effort for development ( 2 chunks) \\
\hline & & & Kequire minmum cost ior deveropment $10 \mathrm{cn}$ \\
\hline Appeal & $\begin{array}{l}\text { Variety } \\
\text { (10 chunks) }\end{array}$ & 1) & Provide multimedia and hyperlinks (10 chunks) \\
\hline $\begin{array}{l}46 \text { chunks } \\
(16 \%) \text { in } 7\end{array}$ & $\begin{array}{l}\text { Flow } \\
\text { (8 chunks) }\end{array}$ & 2) & Help learners concentrate in learning process ( 8 chunks) \\
\hline
\end{tabular}




\begin{tabular}{|c|c|c|c|}
\hline \multirow[t]{2}{*}{$\begin{array}{l}\text { codes across } 4 \\
\text { domains }\end{array}$} & $\begin{array}{l}\text { Motivation } \\
\text { (16 chunks) }\end{array}$ & $\begin{array}{l}3) \\
4) \\
5)\end{array}$ & $\begin{array}{l}\text { Gain and maintain attention and interest ( } 11 \text { chunks) } \\
\text { Add relevance ( } 2 \text { chunks) } \\
\text { Promote enjoying and feeling confident ( } 3 \text { chunks) }\end{array}$ \\
\hline & $\begin{array}{l}\text { Rich Experience } \\
\text { (12 chunks) }\end{array}$ & $\begin{array}{l}\text { 6) } \\
\text { 7) }\end{array}$ & $\begin{array}{l}\text { Offer real world cases ( } 8 \text { chunks) } \\
\text { Promote experiencing and thinking ( } 4 \text { chunks) }\end{array}$ \\
\hline $\begin{array}{l}\text { Extension } \\
71 \text { chunks } \\
(25 \%) \text { in } 6 \\
\text { codes across } 3 \\
\text { domains }\end{array}$ & $\begin{array}{l}\text { Expanded Learning } \\
\text { Opportunities } \\
\text { (19 chunks) } \\
\text { Improved Sharing } \\
\text { and Networking } \\
\text { ( } 33 \text { chunks) } \\
\text { Extended Access } \\
\text { (19 chunks) }\end{array}$ & $\begin{array}{l}\text { 1) } \\
\text { 2) } \\
3) \\
4) \\
\text { 5) }\end{array}$ & $\begin{array}{l}\text { Provide openness to learning ( } 13 \text { chunks) } \\
\text { Promote learning for development ( } 3 \text { chunks) } \\
\text { Include excluded, non-traditional learners ( } 3 \text { chunks) } \\
\text { Promote scholarly sharing and peer review ( } 20 \text { chunks) } \\
\text { Promote collaborative networking at various levels ( } 13 \\
\text { chunks) } \\
\text { Accord with open content licenses (19 chunks) }\end{array}$ \\
\hline
\end{tabular}

Table 3 presents breakdowns of the chunks within each of four instructional priorities for three stages of OER adoption - selection, implementation, and evaluation. "Other" category includes chunks that do not particularly belong to any of these stages.

Table 3

Important Instructional Priorities for OER Use at Three Stages of OER Adoption

\begin{tabular}{lllll}
\hline Stages & Effectiveness & Efficiency & Appeal & Extension \\
\hline Selection & 40 chunks (30\%) & 5 chunks (14\%) & 2 chunks (4\%) & 11 chunks (15\%) \\
Implementation & 29 chunks (22\%) & O chunks (0\%) & 20 chunks (43\%) & 1 chunk (1\%) \\
Evaluation & 22 chunks (16\%) & 11 chunks (31\%) & 10 chunks (22\%) & 28 chunks (40\%) \\
Other & 42 chunks (32\%) & 19 chunks (55\%) & 14 chunks (31\%) & 31 chunks (44\%) \\
Total & 133 chunks (100\%) & 35 chunks (100\%) & $\begin{array}{l}\text { 46 chunks } \\
\text { (100\%) }\end{array}$ & 71 chunks (100\%) \\
\hline
\end{tabular}

As initially assumed, effectiveness was shown to be the most important criterion in using OER in teaching and learning with 133 chunks or $47 \%$ of the total chunks. This was particularly the case when faculty were first selecting OER for their classes; as Table 3 shows, 30\% of the chunks in effectiveness category were chosen at the OER selection stage, compared with $22 \%$ at the implementation stage, and $16 \%$ at the evaluation stage.

The instructors appeared to adopt OER in order to provide better content (78 chunks in learnercentered materials and quality content code categories) and promote active and deeper learning (54 chunks in active methods and deeper learning code categories). This result partly accords with the previous study by Honebein and Honebein (2015) which revealed that instructional designers and teachers tend to choose methods that sacrifice efficiency in favor of effectiveness and appeal. However, in the current study, appeal did not appear to be a strong motive for OER adoption, a matter discussed later in this paper.

It was noticeable in this category that the instructors used OER primarily as supplementary materials or examples to help students master key concepts. This more limited use of OER may be due to instructors finding it difficult to identify OER which closely match their overall objectives, quality requirements, or particular local teaching and learning needs. In this study, four instructors out of ten indicated that they felt that OER did not save time or cost because finding reliable, high quality, and relevant OER was a very time-consuming process. Surveying 420 academics in public and private 
Asian universities, Abeywardena, Chan, and Tham (2013) established that over $57 \%$ of them tended to spend extensive amounts of time locating OER of an acceptable quality and often failed to find what they were looking for.

There are also issues of different teaching and learning cultures and language barriers that need to be taken into account, as Richer and McPherson (2012) argued. All these issues may explain why the instructors mainly use OER as supplementary rather than integral components of their courses or classes. Further investigation is needed in these regards.

It was initially assumed that, as Butcher (2011) and Caswell, Henson, Jensen and Wiley (2008) discovered, instructors use OER to make more efficient use of their time. Surprisingly, this study revealed that efficiency ( 35 chunks, 12\%) was the least concern of most instructors. Only those at two distance teaching universities (Cases 3 and 5 in Table 1) rated efficiency more important (22\% of the total chunks from distance universities related to efficiency against an average of $12 \%$ in the conventional institutions). It may be that OER efficiency is a more important consideration where alternative methods of delivery are encouraged and supported at the institutional level. This matter also warrants further investigation.

As observed above, with 46 chunks, or $12 \%$ of the total chunks, appeal emerged as the second least important reason for adopting OER. As Table 3 shows, appeal was cited as the primary reason for adopting OER at the implementation stage (43\%), e.g., for the purposes of gaining and maintaining attention and interest through the use of multimedia and hyperlinks. However, this factor was not seriously considered when initially selecting OER (4\%) or evaluating OER impact (22\%). While Honebein and Honebein (2015) find that appeal is the most important priority in the digital age, and Bates (2015) includes Novelty in his SECTIONS model for media selection, in this case, it transpired that the instructors selected OER to improve learning effectiveness, but at the implementation stage, they focused mainly on OER appeal to the students. In the age of the massification of higher education for digital natives and the millennials, there may be call to develop instructors' competencies in linking motivational strategies to promoting learning effectiveness and achieving learning outcomes as suggested by Arinto (2013).

Table 2 shows that extension was an important instructional priority in using OER in face-toface/blended and distance learning contexts (71 chunks, $25 \%$ of the total), particularly in Europe and Africa, a point discussed in the following section. The OER movement aims to encourage the use, reuse, remix, repurposing, and redistribution of open and free teaching and learning resources with copyright licenses on a worldwide basis (D'Antoni, 2009). Our study indicates that OER are sometimes being used to broaden learning opportunities, promote sharing and networking, and introduce information and ideas from sources beyond the classroom walls. So some instructors are using OER as both a sustaining and disruptive technology (Christensen, 2003). Sometimes they are using OER as a sustaining technology to support and improve the effectiveness, efficiency and appeal of the existing instructional practices. At other times they are using OER as a disruptive tool for change and innovation. However, as shown in Table 3, while extension was a key concern when evaluating the outcomes of OER applications (40\%), it was not so at the stage of selecting (15\%) and implementing OER (1\%). Further studies are needed to investigate how OER can be used as a 
disruptive technology, bringing about change and transformation in the whole process of teaching and learning.

\section{Regional Differences}

Analysis of the responses to Question 3 revealed significant differences across the regions.

- In the Africa institutions, extension appeared to be the most important criterion for OER adoption (45\%), followed by effectiveness (42\%), efficiency (9\%), and appeal (4\%).

- In the Asia universities, effectiveness was the most important instructional priority for OER use (55\%), followed by extension (16\%), appeal (15\%), and efficiency (13\%).

- In the European institutions, extension was the most important instructional priority for OER use (33\%), followed by effectiveness (27\%), appeal (25\%), and efficiency (14\%).

- In the North American contexts, effectiveness was the most important criterion for OER adoption (42\%), followed by appeal (27\%), extension (19\%), and efficiency (12\%).

It is interesting to note that extension was considered the most important reason for adopting OER in the European and African institutions where the instructors indicated the importance of collaboration in OER development and promoting open access and OER use in universities. This finding may reflect the regional efforts being made to communicate, share and, discuss OER across boundaries.

Europe has a single gateway, the Open Education Europa portal which was launched by the European Commission in 2013. This portal encourages European OER developers to share OER, Open Courseware and MOOCs in different languages with teachers, students and other users across the continent. OER users can also discuss various OER-related topics and share their experiences and ideas in this portal. In addition, all EU countries have committed to developing national qualifications frameworks compatible with the overarching framework of the European Higher Education Area.

In the case of sub-Saharan Africa, developing and deploying OER in the resource-constrained countries can bring many benefits and the development and sharing of OER in higher education is being supported by several organizations such as the African Virtual University (AVU), OER Africa, the South African Institute of Distance Education (SAIDE), and the Teacher Education in SubSaharan Africa (TESSA) Project (Wright \& Reju, 2012). It might therefore be concluded that where there is regional and national leadership, institutions may adopt OER more readily and provide organizational supports and faculty members may make greater use of OER. However, empirical studies examining the actual uses of OER in those regions/nations are needed to confirm this statement.

Asian educators were found to be more concerned with effectiveness. While this study did not investigate the reasons for this, the university culture and policies in Asia may contribute to this. Pang (2011) argues that the globalized economy, commodification of knowledge, retrenchment of the welfare state, and other socio-cultural, economic, and political forces have led to accountability, competitiveness, cost-effectiveness, and quality assurance being brought to the fore in university 
policy-making. These requirements have impacted on management and classroom practices and led instructors to be more concerned to prove and improve educational processes and outcomes.

Effectiveness was also regarded as the most important criterion in OER adoption in the North American Institutions. It might be posited that this is because evaluating the achievement of predetermined instructional objectives has typically been the norm in higher education.

The above findings show that there is scope for further investigation into the impacts of OER, and reasons for the differences in various national and regional settings.

\section{Limitations}

This analysis of regional differences in faculty members' instructional priorities for adopting OER was based upon a limited number of cases. Therefore, the results and discussion require cautious interpretation. The study did not include another important variable, the individual teaching methods and strategies preferred by faculty or encouraged and supported by the institutional managers or teaching and learning culture. Nor did this study pay particular attention to the disruptive aspects of OER adoption even though it revealed that OER were used to create new ways of teaching and learning such as collaborative learning networks. Furthermore, the study did not consider the diversity of OER employed in these cases. These limitations call for further research in wider, crosscultural contexts and to examine the effects of different types of OER on the pedagogical decisionmaking, adoption, adaptation, and actual use of these resources by instructors.

\section{Conclusion: Toward an Elaborated Model of Instructional Priorities for OER Use}

The present study revealed that the three main instructional priorities or reasons - effectiveness, efficiency, and appeal - are important in explaining pedagogical decisions of instructors in higher education for their use of OER in teaching, that extension is another important reason for university faculty to use OER, and that a certain priority is more important than others at the three different stages of pedagogical decision-making - selecting, implementing, and evaluating OER. However, in order to maximize the effects of OER use as suggested in a systems approach to instructional design (Reigeluth \& Carr-Chellman, 2009), we think that instructors need to pay more attention to the four sets of pedagogical motivations for adopting OER at all three stages. Thus our suggestions are as follows:

- At the OER selection stage, the instructors appear to be primarily concerned with effectiveness. We propose that they also need to consider efficiency and extension in selecting OER so that they pay particular attention to sharing OER right from the initial planning stage.

- At the OER implementation stage, the instructors tend to focus on effectiveness and appeal. We propose that they also need to consider extension as an important aspect of adopting OER, not simply as an outcome of OER use. Fully understanding and utilizing the OER`s capacity 
to expand learning opportunities and networking at this stage would help the instructors to adapt OER for various learning purposes. The impact of OER use would be maximized when these three priorities - effectiveness, appeal, and extension - are considered together at this stage.

- At the OER evaluation stage, most of the instructors appear to focus on extension and some on effectiveness. We propose that they also consider the efficiency dimension and whether OER use has actually reduced teaching/learning time, effort and, resource requirements as both emphasize the sharing and collaborative uses of OER.

All these suggest need for an elaborated model which better explains the pedagogical imperatives for using OER in university teaching and learning. Figure 1 presents such model. This prospective model needs to be refined and elaborated based on more empirical studies on OER adoption and use in university teaching and learning.

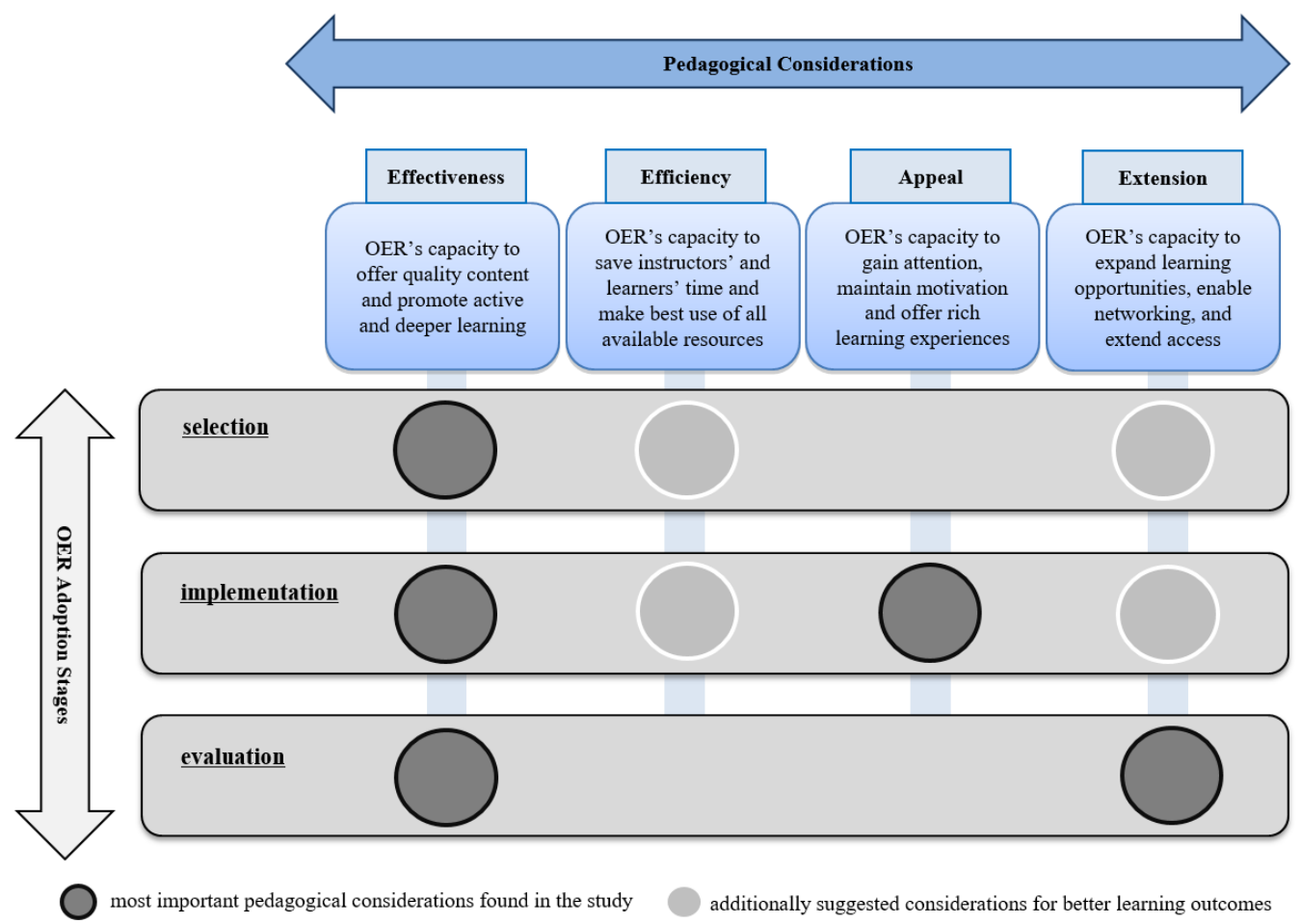

Figure 1. A prospective model of pedagogical considerations at three stages of OER adoption.

\section{Acknowledgements:}

This study was funded by the 2014-2015 Grant-in-Aid for Scientific Research (Kakenhi) from the Japan Society for the Promotion of Society. 


\section{References}

Abeywardena, I., Chan, C., \& Tham, C. (2013). OERScout technology framework: A novel approach to open educational resources search. The International Review of Research in Open and Distributed Learning, 14(4). Retrieved from http://www.irrodl.org/index.php/irrodl/article/view/1505/2634

DOI: 10.19173/irrodl.v14i4.1505

Arinto, P. (2013). A framework for developing competencies in open and distance e-learning. The International Review of Research in Open and Distributed Learning, 14(1), 167-185. Retrieved from http://www.irrodl.org/index.php/irrodl/article/view/1393/2433 DOI: 10.19173/irrodl.v1411.1393

Bates, A. W. (2015). Teaching in a digital age. Retrieved from http://opentextbc.ca/teachinginadigitalage/

Buabeng-Andoh, C. (2012). Factors influencing teachers' adoption and integration of information and communication technology into teaching: A review of the literature. International Journal of Education and Development using Information and Communication Technology, 8(1), 136155. DOI: $10.1080 / 14759390000200096$

Butcher, N. (2011). A basic guide to open educational resources (OER). Vancouver and Paris: COL and UNESCO. Retrieved from http://unesdoc.unesco.org/images/o021/002158/215804e.pdf

Caswell, T., Henson, S., Jensen, M., \& Wiley, D. (2008). Open content and open educational resources: Enabling universal education. The International Review of Research in Open and Distributed Learning, 9(1). Retrieved from http://www.irrodl.org/index.php/irrodl/article/view/469/1001 DOI: 10.19173/irrodl.v9i1.469

Christensen, C. M. (2003). The innovator's solution: Creating and sustaining successful growth. Boston: Harvard Business School Press. DOI: 10.1111/j.0737-6782.2005.116_1.x

Conole, G. (2012). Editorial: Fostering social inclusion through open educational resources. Distance Education, 33(2), 131 - 134. DOI: 10.1080/01587919.2012.700563

Cuellar, M. (2010). Assessing project success: moving beyond the triple constraint. International Research Workshop on IT Project Management, 201O, Paper 13. Retrieved from http://www.michaelcuellar.net/resume/publications/CuellarIRWITPM2010.pdf

D'Antoni, S. (2009). Open educational resources: Reviewing initiatives and issues. Open Learning, 24(1), 3-10. DOI: 10.1080/02680510802625443 
Dhanarajan, G., \& Abeywardena I. S. (2013). Higher education and open educational resources in Asia: An overview. Vancouver: Commonwealth of Learning. Retrieved from http://oldwebsite.col.org/PublicationDocuments/pub PS OER Asia web.pdf

Doering, A., \& Veletsianos, G. (2008). What lies beyond effectiveness and efficiency? Adventure learning design. The Internet and Higher Education, 11(1), 137-144. DOI: 10.1016/j.iheduc.2008.07.004

Falconer, I., McGill, L., Littlejohn, A., \& Boursinou, E. (2013). Overview and analysis of practices with Open Educational Resources in adult education in Europe. Seville, Spain: European Commission Institute for Prospective Technological Studies. Retrieved from http://openeducationeuropa.eu/en/article/Overview-and-Analysis-of-Practices-withOpen-Educational-Resources-in-Adult-Education-in-Europe DOI:10.2791/34193

Groom, C. (2013). A guide to open educational resources. JISC. Retrieved from http://www.jisc.ac.uk/publications/programmerelated/2013/Openeducationalresources.asp x\#Finding\%20and\%2osharing\%20open\%2oeducational\%2oresources

Honebein, P. C., \& Honebein, C. H. (2015). Effectiveness, efficiency, and appeal: Pick any two? The influence of learning domains and learning outcomes on designer judgments of useful instructional methods. Educational Technology Research and Development. DOI: 10.1007/s11423-015-9396-3

Hylén, J. (2006). Open educational resources: Opportunities and challenges. OECD's Centre for Educational Research and Innovation. Paris, France. Retrieved from https://www.oecd.org/edu/ceri/37351085.pdf

Jhangiani, R.S., Pitt, R., Hendricks, C., Key, J., \& Lalonde, C. (2016). Exploring faculty use of open educational resources at British Columbia post-secondary institutions. BCcampus Research Report. Victoria, B.C.: BCcampus. Retrieved from https://bccampus.ca/files/2016/o1/BCFacultyUseOfOER final.pdf

Joint Information Systems Committee. (n.d.). Case studies of OER use. Retrieved from http://www.webarchive.org.uk/wayback/archive/20140614115352/http://www.jisc.ac.uk/w hatwedo/programmes/elearning/oer2/casestudies.aspx

Jung, I. S., Sasaki, T., \& Latchem, C. (2016). A framework for assessing fitness for purpose in open educational resources. Universities and Knowledge Society Journal (RUSC), 13(1). DOI: 10.1186/s41239-016-0002-5

Kortemeyer, G. (2013). Ten years later: Why open educational resources have not noticeably affected higher education, and why we should care. Educause Review Online. Retrieved from http://www.educause.edu/ero/article/ten-years-later-why-open-educational-resourceshave-not-noticeably-affected-higher-education-and-why-we-should-ca 
Leacock, T. L., \& Nesbit, J. C. (2007). A framework for evaluating the quality of multimedia learning resources. Educational Technology \& Society, 1O(2), 44-59.

McGreal, R. (2013). Creating, using and sharing open educational resources. Vancouver: Commonwealth of Learning. Retrieved from https://www.fosteropenscience.eu/sites/default/files/pdf/514.pdf

McGreal, R., Kinuthia, W., \& Marshall, S. (2013). The International Review of Research in Open and Distributed Learning, 14(2), i-iv. Retrieved from http://www.irrodl.org/index.php/irrodl/article/view/1549/2501

Mtebe, J., \& Raisamo, R. (2014). Challenges and instructors' intention to adopt and use open educational resources in higher education in Tanzania. International Review of Research in Open and Distributed Learning, 15(1). Retrieved from http://www.irrodl.org/index.php/irrodl/article/view/1687/2771 DOI: 10.19173/irrodl.v15i1.1687

Murphy, A. (2013). Open educational practices in higher education: Institutional adoption and challenges. Distance Education, 34(2), 201-217. DOI: 10.1080/01587919.2013.793641

Pang, N. S. (2011). Educational governance and management in Sinic society. In Y. Zhao, J. Lei, G. Li, M. F. He, K. Okano, N. Megahed, D. Gamage, \& H. Ramanathan (Eds), Handbook of Asian education: A cultural perspective (pp. 8-28). New York, NY: Routledge. DOI: 10.14507/epaa.v18n5.2010

Petrides, L., Jimes, C., Middleton-Detzner, C. Walling, J., \& Weiss, S. (2011). Open textbook adoption and use: implications for teachers and learners. The Journal of Open, Distance and $e$ Learning, 26(1), 39-49. DOI: 10.1080/02680513.2011.538563.

Reigeluth, C. M. (1999). What is instructional-design theory and how is it changing? In C. M. Reigeluth (Ed.), Instructional-design theories and models: A new paradigm of instructional theory (Vol. II, pp. 5-29). Mahwah, NJ: Lawrence Erlbaum Associates.

Reigeluth, C. M., \& Carr-Chellman, A. A. (2009). Understanding instructional theory. In C. M. Reigeluth, \& A. A. Carr-Chellman (Eds.), Instructional design theories and models, Building a common knowledge base (Vol. III, pp. 3-26). New York and London: Routledge.

Reigeluth, C. M., \& Frick, T. W. (1999). Formative research: A methodology for creating and improving design theories. In C. M. Reigeluth (Ed.), Instructional-design theories and models: A new paradigm of instructional theory (Vol. II, pp. 633-652). New York and London: Routledge.

Reynolds, R. (2012). Obstacles to faculty adoption of OER and open textbooks. The Learning Lot. May 15, 2012. Retrieved from http://thelearninglot.blogspot.com.au/2012/05/obstacles-tofaculty-adoption-fo-oer.html 
Richter, T., \& McPherson, M. (2012) Open educational resources: Education for the world? Distance Education, 33(2), 201-219. DOI: 10.1080/01587919.2012.692068

SCORE. (n.d.) Case studies. Retrieved from http://www.open.ac.uk/score/case-studies

Wiley, D. (Ed.) (2008). OER handbook for educators. Beaumont: Center for Open and Sustainable Learning. Retrieved from http://wikieducator.org/OER_Handbook/educator_version one

Wiley, D., Bliss, T. J., \& McEwen, M. (2014). Open Educational Resources: A review of the literature. In J. M. Spector, M. D. Merrill, J. Elen, \& M. J. Bishop. (Eds.), Handbook of research on educational communications and technology (pp. 781-789). New York: Springer. DOI: 10.1007/978-1-4614-3185-5_63

Wilson, B., Parrish, P., \& Veletsianos, G. (2008). Raising the bar for instructional outcomes: Towards transformative learning experiences. Educational Technology, 48(3), 39-44.

Wright, C., \& Reju, S. (2012). Developing and deploying OERs in sub-Saharan Africa: Building on the present. International Review of Research in Open and Distributed Learning, 13(2), 181220. Retrieved from http://www.irrodl.org/index.php/irrodl/article/view/1185/2161 DOI: 10.19173/irrodl.v13i2.1185 